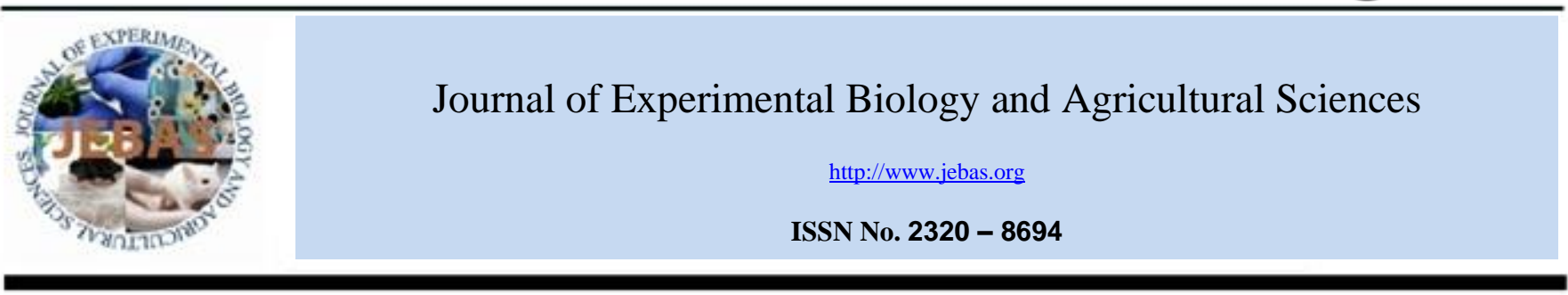

\title{
GENETIC VARIATION IN MAIZE INBRED LINES UNDER TEMPERATE CONDITIONS
}

\author{
Z.A. Dar ${ }^{*}$, A.A. Lone, B.A. Elahi, S.A. Dar., G. Ali, I. Abidi., R.A. Lone ., S. Gulzar and N. Yousuf \\ D(K)ARS, Budgam, SKUAST-Kashmir, 190001
}

Received - January 27, 2017; Revision - March 21, 2017; Accepted - April 18, 2017

Available Online - May 12, 2017

DOI: http://dx.doi.org/10.18006/2017.5(2).215.219

\section{KEYWORDS \\ Maize \\ Component analysis \\ Gene action \\ Diallel}

Maize Inbreds

\begin{abstract}
Present study was carried out to generate information on gene action using Hayman's component of diallel analysis. The experimental material comprised 30 crosses which were generated by crossing between six maize inbred lines in a diallel mating design during Kharif 2014. These 30 crosses along with standard checks viz., Vivek Hybrid-45 and SMC-7 were evaluated in randomized block design in three replications during Kharif 2015 and Kharif 2016. Significant variation was observed for all studied traits during both the seasons. Both additive (D) and dominance $\left(\mathrm{H}_{1}\right.$ and $\left.\mathrm{H}_{2}\right)$ components of genetic variance were found significant under the study. Preponderance of non-additive gene action was observed for all traits under study. Average degree of dominance was in over dominance range for all characters. The gene distribution was asymmetrical for all traits. The value of KD / KR indicated presence of excess of dominant genes for all traits except 100 grain weight and ear girth. Heritability of most of the traits was low to medium.
\end{abstract}

* Corresponding author

E-mail: zahoorpbg@gmail.com (Z.A. Dar)

Peer review under responsibility of Journal of Experimental Biology and Agricultural Sciences.

Production and Hosting by Horizon Publisher India [HPI] (http://www.horizonpublisherindia.in/).

All rights reserved.
All the article published by Journal of Experimental Biology and Agricultural Sciences is licensed under a Creative Commons Attribution-NonCommercial 4.0 International License Based on a work at www.jebas.org.

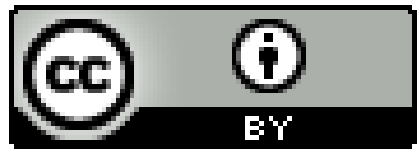




\section{Introduction}

Maize (Zea mays L.) is a cereal crop, grown widely throughout the world in a range of agro-ecological environments that include tropics, sub-tropics and temperate regions; from sea level to $3000 \mathrm{~m}$ above (Morris, 2002) both under irrigated to semi-arid conditions. Having originated in Mexico, maize is now grown at least in 164 countries around the world and a tremendous choice is available as regards varieties maturing in 85 days to more than 200 days (Brink \& Belay, 2006) with variability in grain colour, size and texture. Maize has a worldwide significance as food, feed and as a good source of starch, protein and oil. Many countries rely on maize as a primary staple as it meets the protein and calorie requirements of the human beings (Vasal, 2002). Hayman's approach of diallel analysis (Hayman, 1954) is most suited to determine the type of gene action, controlling the expression of plant in early generations, which is a prerequisite for genetic improvement of any crop. Knowing the gene actions governing the traits of interest, plant breeders can devise suitable strategies to develop novel germplasm (Kearsey \& Pooni, 1998). Thus the present study was conducted over two environments, to have reliable estimates of the various components of genetic variation for traits related to in a set of elite maize lines.

\section{Materials and Methods}

Six maize inbred lines viz. KDM-914A, KDM-895A, KDM500, KDM-362A, KDM-343A and KDM-340A were crossed in a diallel mating design during Kharif season of 2014 and all 30 possible single crosses, along with two standard checks viz., Vivek Hybrid-45 and SMC-7 were evaluated in a randomized block design (RBD) with three replications during Kharif season of 2015 and Kharif season of 2016 at Dryland (Karewa) Agricultural Research Station, Budgam, Jammu and Kashmir, India. Observations were recorded on morphological traits viz. days to $50 \%$ tasseling, $50 \%$ silking, plant height, ear length $(\mathrm{cm})$, ear girth $(\mathrm{cm})$, number of kernel rows per ear, number of kernels per row, hundred grain weight and grain yield per plant (in grams). Diallel component analysis (Hayman, 1954) was performed with the help of statistical software Windostat version 9.1

\section{Results and Discussion}

Analysis of variance (ANOVA) for all the characters, over the environments, showed significant differences among environments (Kharif seasons of 2015 and 2016), genotypes and genotype $\times$ environment interaction (Table 1). Significant genotype $\times$ environment interaction suggested the differential response of genotypes over the environments. Analysis of variance for all the characters under study in two different environments indicated significant differences among the treatments, i.e. six parents and 30 diallel set of crosses. Significant variation among the yield traits in maize was earlier reported by Hussain et al. (2009), Haq et al. (2009), Kumar et al. (2012), Dawod et al. (2012); Sarac \& Nedelea (2013a) and Dar et al. (2017).

The components of genetic variation were estimated for all the characters and pooled results are presented in Table 2 . Analysis of the components of genetic variance revealed that both additive (D) and dominance components $\left(\mathrm{H}_{1}\right.$ and $\left.\mathrm{H}_{2}\right)$ were significant for all the traits. This finding suggested the involvement of both these dominance components $\left(\mathrm{H}_{1}\right.$ and $\left.\mathrm{H}_{2}\right)$ in the inheritance of these traits, however greater magnitude of dominance component demonstrated greater role of dominance component in the inheritance of these traits. The distribution of alleles in the parents revealed that positive and negative alleles at these loci are not in equal proportion in parents as $\mathrm{H}_{1}$ exceeds $\mathrm{H}_{2}$ and dominance gene action resulted mainly from positive gene action. Dawod et al. (2012) reported relatively higher estimates of dominance components than additive component for kernel rows ear ${ }^{-1}$, kernels row $^{-1}$ and grain yield which are in line with the present findings. Estimation of $\mathrm{H}_{2}$ effects was found to be significant and positive for all traits studied revealing that net dominance effect over all the loci in heterozygote was more and that too it exhibited dominance in positive direction. Value of $\mathrm{F}$ estimate was positive and non significant for all traits studied except kernels row $^{-1}$ thus revealing contribution of more recessive alleles towards dominance deviation.

On the contrary, the value of $\mathrm{F}$ estimate was significant and positive for kernels row $^{-1}$ revealing higher frequency of dominant alleles in the parents for these traits. Proportions of components of genetic variations were calculated and results are presented in Table 3 . The average degree of dominance indicated over-dominance for all the traits, over the environments which suggested the importance of non-additive type of gene action for all the traits. Over-dominance for ear traits and grain yield, similar to present findings was also reported by Kumar et al. (2012), Dawod et al. (2012) and Sarac \& Nedelea (2013a, 2013b). The study of proportions of various genetic components of variance revealed that the proportion of $\left(\mathrm{H}_{2} / 4 \mathrm{H}_{1}\right)$ was less then 0.25 for all the studied traits indicating asymmetrical gene distribution in the parents. Asymmetric distribution of genes for kernels rows ear ${ }^{-1}$ was reported by Khodarahmpour (2011) which supports the present findings. Also Zare et al. (2011) observed values of $\mathrm{H}_{2} / 4 \mathrm{H}_{1}$ away from 0.25 , showing asymmetric distribution of positive and negative dominant genes for kernel rows ear ${ }^{-1}$ and kernels row ${ }^{-1}$ in their study. The genetic ratio KD/KR which gives the proportion of dominant and recessive alleles in the parent was found to be greater than unity for all traits studied except for ear girth and 100 -grain weight where it was less than unity. This suggested that barring ear girth and 100-grain weight there was higher proportion of dominant alleles in the parents for traits studied and the recessive and dominant genes where nearly equal for traits viz., 100-grain weight and ear girth. Similar to the present findings the prevalence of dominant genes for ear related traits and grain yield was reported by Zare et al. (2011) and Kumar et al. (2012).

Journal of Experimental Biology and Agricultural Sciences http://www.jebas.org 
Table 1 Pooled analysis of variance for different characters in maize

\begin{tabular}{|c|c|c|c|c|c|c|c|c|c|c|c|}
\hline S No & Source of Variation & d.f & $\begin{array}{c}\text { Days to } 50 \% \\
\text { anthesis }\end{array}$ & $\begin{array}{l}\text { Days to } 50 \% \\
\text { silking }\end{array}$ & $\begin{array}{l}\text { Plant height } \\
\quad(\mathrm{cm})\end{array}$ & $\begin{array}{l}\text { Ear length } \\
\quad(\mathrm{cm})\end{array}$ & $\begin{array}{l}\text { Ear girth } \\
\quad(\mathrm{cm})\end{array}$ & $\begin{array}{l}\text { Kernel row } \\
\text { ear-1 }\end{array}$ & $\begin{array}{c}\text { Kernels } \\
\text { row }^{-1}\end{array}$ & $\begin{array}{l}\text { 100-grain } \\
\text { weight }(\mathrm{g})\end{array}$ & $\begin{array}{c}\text { Grain yield } \\
\text { plant }^{-1}(\mathrm{~g})\end{array}$ \\
\hline 1. & Environments & 1 & $11410.630 * *$ & $11767.210^{* *}$ & $51406.20 * *$ & $395.877 * *$ & $86.889 * *$ & 0.195 & $1410.320 * *$ & $149.291 * *$ & $39540.790 * *$ \\
\hline 2. & Treatments & 35 & $62.657 * *$ & $60.389^{* *}$ & $5602.520 * *$ & $16.962 * *$ & $4.487 * *$ & $10.758 * *$ & $86.745^{* *}$ & $60.830 * *$ & $3576.861^{* *}$ \\
\hline 3. & Parents & 5 & $22.364 * *$ & $23.794 * *$ & $4633.733 * *$ & $8.083^{* *}$ & $2.737 * *$ & $15.233 * *$ & $55.635 * *$ & $41.463 * *$ & $919.779 * *$ \\
\hline 4. & Hybrids & 29 & $28.809 * *$ & $30.670 * *$ & $2524.578 * *$ & $6.959 * *$ & $2.476^{* * *}$ & $9.485^{* *}$ & $56.725 * *$ & $42.760 * *$ & $1468.898^{* * *}$ \\
\hline 5. & Parents v. s Hybrids & 1 & $2737.609 * *$ & $2410.395 * *$ & $6301.400 * *$ & $799.409 * *$ & $149.165 * *$ & $43.851 * *$ & $3652.503 * *$ & $1565.938 * *$ & $169621.302 *$ \\
\hline 6. & Treatment x Environments & 35 & $4.494 * *$ & $3.072 * *$ & $637.316^{* *}$ & $5.178^{* *}$ & $1.52 * *$ & $1.936^{* *}$ & $19.873 * *$ & $5.283^{* *}$ & $389.46^{* *}$ \\
\hline 7. & Parent $\mathrm{x}$ Environments & 5 & $5.385^{* * *}$ & $3.252^{* * *}$ & $507.004 * *$ & $1.065^{*}$ & $0.571^{*}$ & 0.315 & $7.990 * *$ & $2.358 * *$ & 39.916 \\
\hline 8. & Hybrids x Environments & 29 & $4.089 * *$ & $2.860^{* *}$ & $632.688^{* *}$ & $5.061 * *$ & $1.516^{* * *}$ & $2.217 * *$ & $18.892 * *$ & $5.791 * *$ & $385.51 * *$ \\
\hline 9. & $\begin{array}{l}\text { Parent v. s Hybrids x } \\
\text { Environments }\end{array}$ & 1 & $15199^{* *}$ & $14.467 * *$ & $2337.569^{* *}$ & $59.126^{* *}$ & $7.133^{* *}$ & $2.447^{* *}$ & $210.735^{* *}$ & $9.763^{* * *}$ & $53778.4^{* *}$ \\
\hline 10. & Error & 70 & 1.143 & 1.314 & 31.848 & 0.494 & 0.247 & 0.364 & 1.918 & 0.911 & 27.199 \\
\hline
\end{tabular}

Table 2 Estimates of genetic parameters for grain yield and other attributes in maize

\begin{tabular}{|c|c|c|c|c|c|c|c|c|c|c|}
\hline \multirow[t]{2}{*}{$\begin{array}{l}\text { S. } \\
\text { No. }\end{array}$} & \multirow[t]{2}{*}{ Components } & $\begin{array}{c}\text { Days to } 50 \% \\
\text { anthesis }\end{array}$ & $\begin{array}{c}\text { Days to } 50 \% \\
\text { silking } \\
\end{array}$ & Plant height $(\mathrm{cm})$ & $\begin{array}{c}\text { Ear length } \\
(\mathrm{cm})\end{array}$ & $\begin{array}{c}\text { Ear girth } \\
(\mathbf{c m})\end{array}$ & $\begin{array}{c}\text { Kernel row } \\
\text { ear }^{-1}\end{array}$ & Kernels row $^{-1}$ & $\begin{array}{l}\text { 100- grain } \\
\text { weight }(\mathrm{g})\end{array}$ & Grain yield plant $^{-1}(\mathrm{~g})$ \\
\hline & & Pooled & Pooled & Pooled & Pooled & Pooled & Pooled & Pooled & Pooled & Pooled \\
\hline 1. & $\widehat{D}$ & $5.55 \pm 1.87 * *$ & $5.62 \pm 1.80 * *$ & $11150.72 \pm 86.43^{* *}$ & $1.89 \pm 0.70$ & $0.62 \pm 0.12 * *$ & $3.72 \pm 0.42$ & $13.68 \pm 2.17^{* *}$ & $10.14 \pm 1.12^{* *}$ & $222.40 \pm 95.55^{*}$ \\
\hline 2. & $\widehat{H_{1}}$ & $41.68 \pm 3.73 * *$ & $39.84 \pm 3.59 * *$ & $2414.44 \pm 152.90^{* *}$ & $11.44 \pm 1.40^{* *}$ & $2.30 \pm 0.24 * *$ & $4.05 \pm 0.84^{* *}$ & $53.66 \pm 4.34 * *$ & $30.12 \pm 2.24 * *$ & $2290.73 \pm 191.16^{* *}$ \\
\hline 3. & $\widehat{H_{2}}$ & $36.17 \pm 3.11 * *$ & $34.06 \pm 2.99 * *$ & $2253.81 \pm 127.19^{* * *}$ & $10.18 \pm 1.16^{* * *}$ & $2.19 \pm 0.20^{* *}$ & $3.39 \pm 0.70^{* *}$ & $47.31 \pm 3.61 * *$ & $26.66 \pm 1.86^{* *}$ & $2077.34 \pm 159.01^{* *}$ \\
\hline 4. & $\widehat{h_{2}}$ & $225.64 \pm 2.08 * *$ & $199.12 \pm 2.0 * *$ & $17897.58 \pm 82.04 * *$ & $66.03 \pm 0.78 * *$ & $12.24 \pm 1.13 * *$ & $3.59 \pm 0.47 * *$ & $301.95 \pm 2.41 * *$ & $128.69 \pm 1.25^{* *}$ & $14034.06 \pm 106.32 * *$ \\
\hline 5. & $\hat{F}$ & $2.87 \pm 4.23$ & $2.36 \pm 4.07$ & $124.16 \pm 173.23$ & $1.37 \pm 1.59$ & $0.03 \pm 0.27 * *$ & $0.70 \pm 0.95^{* *}$ & $8.68 \pm 4.92$ & $1.17 \pm 2.54$ & $25.39 \pm 216.57$ \\
\hline 6. & $\hat{E}$ & $0.29 \pm 0.52$ & $0.33 \pm 0.50$ & $7.96 \pm 21.20$ & $0.12 \pm 0.19$ & $0.06 \pm 0.3$ & $0.09 \pm 0.12^{* *}$ & $0.48 \pm 0.60$ & $0.23 \pm 0.31$ & $6.80 \pm 26.50$ \\
\hline
\end{tabular}

[*, ** significant at 5 and 1 per cent level, respectively, D-variance component due to additive genetic effects; H 1 - variance component due to dominance deviations; H 2 - estimate of dominance genetic variance due to proportion of positive and negative genes; $h 2$ - net dominance effect; $F$ - mean of covariance of additive and dominance effects over all the arrays; $E$ - environmental component of variation.] 


\begin{tabular}{|c|c|c|c|c|c|c|c|}
\hline 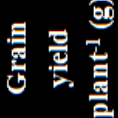 & 冚 & $\vec{\sim}$ & 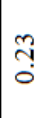 & 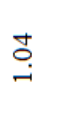 & & $\frac{0}{0}$ & $\begin{array}{l}+ \\
\infty \\
\infty \\
\infty \\
-1\end{array}$ \\
\hline 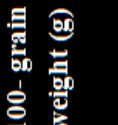 & : & $\stackrel{2}{\stackrel{2}{Z}}$ & $\stackrel{\text { ָ̦ }}{\circ}$ & ণ़े & & $\begin{array}{l}m \\
\infty \\
\dot{\gamma}\end{array}$ & ڤ̆ \\
\hline 党 & : & $\stackrel{\infty}{\stackrel{一}{-}}$ & 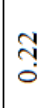 & $\stackrel{\infty}{\text { m}}$ & & $\begin{array}{l}\infty \\
\text { m. } \\
b\end{array}$ & ๙2 \\
\hline 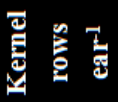 & 范 & $\stackrel{\text { O̦ }}{-}$ & $\vec{\jmath}$ & 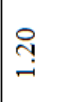 & & $\stackrel{1}{\circ}$ & $\begin{array}{l}n \\
0 \\
0 \\
0\end{array}$ \\
\hline 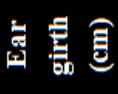 & 冚 & ๙ุ & $\stackrel{+}{i}$ & $\hat{a}$ & & $\begin{array}{l}\circ \\
\text { in }\end{array}$ & 年 \\
\hline 总䓌兽 & 宛 & 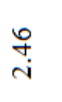 & 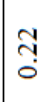 & $\stackrel{n}{m}$ & & 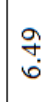 & $\stackrel{2}{2}$ \\
\hline 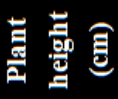 & : & $\stackrel{\text { ? }}{\rightarrow}$ & 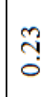 & $\stackrel{\infty}{\circ}$ & & $\stackrel{+}{\circ}$ & $\stackrel{m}{m}$ \\
\hline 里 照 & : & $\begin{array}{l}0 \\
\text { i }\end{array}$ & $\vec{\jmath}$ & $\stackrel{\square}{\leftrightarrows}$ & & $\begin{array}{l}n \\
\infty \\
\text { n. }\end{array}$ & $\begin{array}{l}6 \\
1 \\
1\end{array}$ \\
\hline 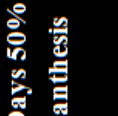 & : & $\frac{\dot{r}}{i}$ & 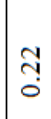 & 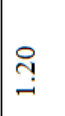 & & 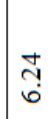 & $\begin{array}{l}0 \\
\\
\end{array}$ \\
\hline & 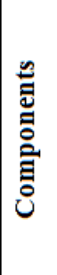 & 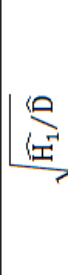 & $\frac{\operatorname{lr}^{-5}}{\operatorname{lir}^{N}}$ & \begin{tabular}{r} 
오 \\
$\|$ \\
"山 \\
+ \\
+ \\
结 \\
\multirow{4}{*}{}
\end{tabular} & 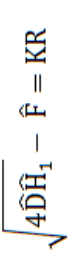 & 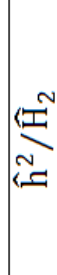 & 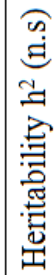 \\
\hline & $\underset{\dot{n}}{\dot{z}}$ & - & $N$ & $m$ & & $\nabla$ & $n$ \\
\hline
\end{tabular}

The proportion of average degree of dominance measured form genetic components of variance $\left(\mathrm{H}_{1} / \mathrm{D}\right)^{0.5}$ was more than unity thus revealing over dominance for the traits studied. The narrow sense heritability was highest for kernel rows ear ${ }^{-1}$ $(50.07 \%)$ which was followed by plant height $(33.13 \%), 100$ grain weight $(23.95 \%)$ and kernels row $^{-1}(22.58 \%)$ (Table 3$)$. The moderate heritability for kernel rows ear $^{-1}$ suggested effectiveness of selection for improvement of this trait. Ear length, ear girth and grain yield plant ${ }^{-1}$ exhibited low heritabilities ( $15.19 \% 19.45 \%$ and $18.84 \%)$ over the seasons suggesting lower selection efficiency for these traits. Low narrow sense heritability for grain yield $(\sim 10 \%)$ was reported by Khodarahmpour (2011), and Sarac \& Nedelea (2013b), which also reported relatively less genetic variation for yield in their material. Similarly, moderate narrow sense heritability estimates for kernel rows ear $^{-1}(48.4 \%)$ and kernels row $^{-1}$ $(43.7 \%)$ were reported by Zare et al. (2011). In conclusion, in this study the prevalence of greater magnitude of non additive genetic component of variance than additive component suggesting that heterosis breeding would be beneficial to utilize the dominance gene effects of these traits. The low narrow sense heritability of few traits viz., ear length, ear girth and gain yield plant ${ }^{-1}$ suggested that selection for these traits may not be effective and reliable. However, owing to the high heritabilities of traits viz., kernel rows ear ${ }^{-1}, 100$ grain weight and kernels row ${ }^{-1}$ selection may be more reliable.

\section{Conflict of interest}

Authors would hereby like to declare that there is no conflict of interests that could possibly arise.

\section{References}

Brink M, Belay G (2006) Plant Resources of Tropical Africa 1. Cereals and pulses. PROTA Foundation, Wageningen, Netherlands/Backhuys Publishers, Leiden, Netherland/CTA, Wageningen, Netherland. Pp.233.

Dawod KM, Al-Falahy MAH, Mohammad ASA (2012) Genetic variations and gene effect controlling grain yield and some of its components in maize. Journal of Agricultural Science and Technology B 2: 814-823.

Dar ZA, Lone AA, Wani SH, Alaie B, Abidi I, Ali G, Habib M, Mohammad IA, Wani MA (2017) Analysis of combining ability in maize (Zea mays L.) under temperate conditions. International Journal of Agriculture Sciences 9 : 3647-3649.

Haq MI, Ajmal SU, Malik HN, Munir M (2009) Genetic analysis of grain yield and components in maize. Sarhad Journal of Agriculture 25: 187-195.

Hayman BI (1954) The theory and analysis of diallel crosses. Genetics 39: 789-809.

Hussain I, Ahsan M, Saleem M, Ahmad A (2009) Gene action studies for agronomic traits in maize under normal and water stress conditions. Pakistan Journal of Agricultural Sciences 46: 107-112.

Kearsey MJ, Pooni HS (1998) Genetical analysis of quantitative traits, 2nd ed. Stanley Thomas Pub. Ltd. 
Khodarahmpour Z (2011) Genetic control of different traits in maize inbred lines (Zea mays L.) using graphical analysis. African Journal of Agricultural Research 6: 1661-1666. DOI: 10.5897/AJAR10.896.

Kumar TS, Reddy DM, Naik VS, Parveen SI, Subbaiah PV (2012) Gene action for yield and morpho-physiological traits in maize (Zea mays L.) inbred lines. Journal of Agricultural Science 4: 13-16. DOI: http://dx.doi.org/10.5539/jas.v4n5p13.

Morris ML (2002) Impacts of International Maize Breeding Research in Developing Countries, 1966-98. Mexico, D.F.: CIMMYT. Pg-4.
Sarac N, Nedelea G (2013a) Study of inheritance for ear length in maize using diallel analysis. Journal of Horticulture, Forestry and Biotechnology 17: 281-284.

Sarac N, Nedelea G (2013b) Estimation of gene action and genetic parameters for ear yield in maize. Journal of Horticulture, Forestry and Biotechnology 17: 277-280.

Vasal SK (2002) Quality protein maize: Overcoming the hurdles. Journal of Crop Production 6: 193-227. DOI: http://dx.doi.org/10.1300/J144v06n01_11.

Zare M, Choukan R, Bihamta MR, Heravan EM, Kamelmanesh MM (2011) Gene action for some agronomic traits in maize (Zea mays L.). Crop Breeding Journal 1: 133141. 